\title{
Algoritma Fisher-Yates Pada Game Edukasi Aksara Sunda Cacarakan Berbasis Android Sebagai Media Pembelajaran Untuk Anak Usia Dini
}

\author{
Asep Anang ${ }^{1}$, Acep Irham Gufroni ${ }^{2}$ \\ ${ }^{1,2,3}$ Jurusan Informatika, Universitas Siliwangi, Tasikmalaya, Indonesia \\ Iasean080@gmail.com,2acep@unsil.ac.id
}

\section{INFORMASI ARTIKEL}

Sejarah Artikel:

Diterima Redaksi: 30-12-2021

Revisi Akhir: 23-01-2022

Diterbitkan Online: 25-01-2022

\begin{tabular}{l} 
KATA KunCI \\
\hline Aksara Sunda Cacarakan, \\
Android, \\
Algoritma Fisher Yates Shuffle, \\
Game Development Life Cycle (GDLC), \\
Skala Likert \\
KoRESPONDENSI \\
\hline
\end{tabular}

E-mail: asean080@gmail.com

\begin{abstract}
Aksara Sunda Cacarakan merupakan salah satu warisan budaya Indonesia. Pelestarian Aksara Sunda Cacarakan adalah tugas yang harus dilakukan oleh masyarakat Indonesia sebagai salah satu cara untuk melindungi keberadaan Aksara Sunda Cacarakan, salah satunya dengan mengetahui jenis Aksara Sunda Cacarakan yang dibagi menjadi 4 bagian, seperti ngalagena, angka, swara dan rarangken. Implementasi dari Teknologi Informasi (TI) merupakan suatu keharusan untuk dilakukan sebagai inovasi untuk mendapatkan berbagai macam informasi. Upaya untuk memperkenalkan Aksara Sunda adalah dengan membuat Game Edukasi berbasis Android, Game edukasi dibangun dengan tujuan meningkatkan kemampuan anak-anak dalam pengenalan aksara Sunda Cacarakan, maka untuk penelitian ini, dibuat sebuah Game edukasi berbasis android dengan menggunakan Algoritma Fisher yates Shuffle. Algoritma Fisher Yates adalah algoritma untuk menghasilkan permutasi acak dari himpunan terbatas, dengan kata lain untuk mengacak suatu himpunan. Algoritma Fisher yates shuffle di terapkan dalam pengacakan soal di dalam Game edukasi, Model sistem untuk mendukung penelitian ini menggunakan versi Game Development Life Cycle (GDLC), yang mengemukakan enam langkah (Initiation, Pre-Production, Production, Testing, Beta, dan Release). Penilaian tanggapan dari responden menggunakan skala Likert. Skala likert memilrata-rata rumus index yang diperoleh dari responden, aspek kegunaan sebesar 80,5\%, aspek kualitas interaksi sebesar 87,5\% dan aspek kualitas informasi sebesar $82 \%$, termasuk dalam kategori sangat setuju, sehingga game dinyatakan layak untuk digunakan dan dipublikasikan.
\end{abstract}

\section{Pendahuluan}

Keberadaan aksara sunda kaganga atau lebih dikenal dengan aksara Sunda Cacarakan merupakan salah satu warisan budaya indonesia memiliki peranan penting sebagai sebuah identitas dan jati diri bangsa Indonesia. Pelesetarian aksara sunda merupakan sebuah tugas yang harus dilakukan oleh masyarakat Indonesia dalam upaya melindungi salah satu aset kebudayaan bangsa Indonesia tersebut, agar tidak tergerus oleh jaman maupun adanya pengakuan dari negara lain.

Inovasi dengan memanfaatkan Teknologi Infomasi (TI) ke dalam dunia pendidikan perlu dilakukan demi mempermudah tingkat pemahaman seseorang dalam memahami sebuah informasi. Game atau permainan adalah sesuatu yang dapat dimainkan dengan aturan tertentu sehingga ada yang menang dan ada pula yang kalah, biasanya dalam konteks tidak serius dapat dikatakan hanya tujuan refreshing. Game sudah sangat familiar untuk masyarakat kita saat ini, game banyak digunakan sebagai alternatif hiburan tidak hanya anak, remaja namun juga orangtua baik pria maupun wanita.

Perlu adanya sebuah evaluasi pemahaman pengguna mengenai aksara sunda yang telah di pelajari. Evaluasi pemahaman tersebut di terapkan ke dalam sebuah Game dengan genre quis, keluarnya soal bisa dibuat dengan acak dan cepat. Metode acak dilakukan dengan Algoritma Fisher-Yates Suffhel yang diterapkan pada Game edukasi. Algoritma Fisher-Yates dipilih karena algoritma ini merupakan metode pangacakan yang lebih baik atau 
dapat dikatakan sesuai untuk pengacakan deret angka (array), dengan waktu eksekusi yang cepat serta tidak memerlukan waktu yang lama untuk melakukan suatu pengacakan. Adapun tujuan dari penelitian ini adalah untuk merancang dan membangun aplikasi Game edukasi (Sunda Cacarakan) berbasis Android untuk memberikan latihan dan pemahaman kepada pengguna (anak usia dini) sehingga dapat memahami aksara Sunda Cacarakan.

\section{Penelitian Terkait}

Penelitian sebelumnya yang merupakan acuan dalam penerapan metode dasar penelitian adalah:

Tabel I Penelitian Terdahulu

\begin{tabular}{|c|c|c|}
\hline \multirow{2}{*}{$\begin{array}{c}\text { Peneliti } \\
\text { Mhd Arief Hasan, } \\
\text { Supriadi,Zamzami }\end{array}$} & Judul & Tahun \\
\hline & $\begin{array}{l}\text { Implementasi Algoritma Fisher- } \\
\text { Yates Untuk Mengacak Soal Ujian } \\
\text { Online Penerimaan Mahasiswa } \\
\text { Baru (Studi Kasus : Universitas } \\
\text { Lancang Kuning Riau) }\end{array}$ & 2017 \\
\hline Dyah Ayu Irawati & $\begin{array}{l}\text { "PENERAPAN ALGORITMA } \\
\text { FISHER-YATES PADA } \\
\text { PENGACAKAN SOAL GAME } \\
\text { ARITMATIKA" }\end{array}$ & 2017 \\
\hline Bobby Prasetyo & $\begin{array}{l}\text { PERANCANGAN MEDIA } \\
\text { PEMBELAJARAN BERHITUNG } \\
\text { BERBASIS MULTIMEDIA } \\
\text { FLASH }\end{array}$ & 2015 \\
\hline
\end{tabular}

\section{Metodologi}

Tahapan penelitian ini menjelaskan langkah-langkah untuk melakukan penelitian, dijelaskan pada gambar 1 sebagai berikut :

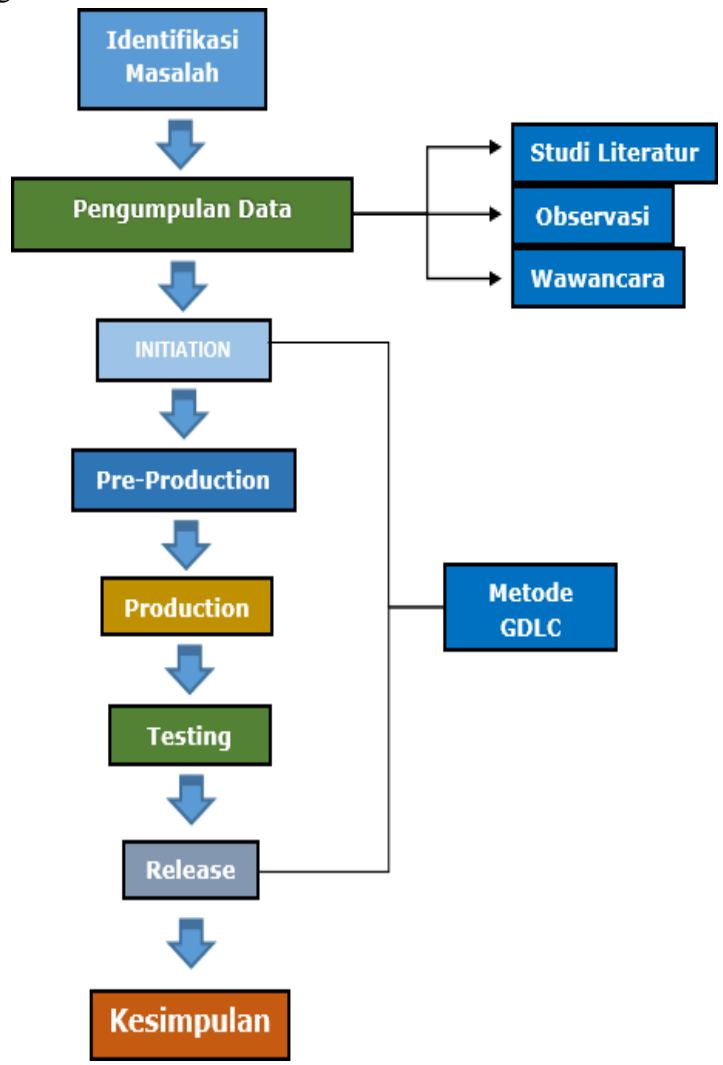

Gambar 1. Tahapan Penelitian

\subsection{Identifikasi Masalah}

Pada identifikasi masalah disini ialah dengan melakukan pengumpulan data dari mulai observasi sampai studi pustaka guna mengetahui data apa yang dibutuhkan dan membuat sebuah perancangan untuk membuat sebuah game edukasi yang di inginkan.

\subsection{Pengumpulan Data}

Metode pengumpulan data dilakukan dengan mengidentifikasi dan membuat alur perancangan yang akan dilaksanakan, agar proses pencarian data tidak terjadi penyimpangan dalam mengemukakan suatu tujuan yang ingin dicapai.

\subsection{Metode Pengembangan}

Metode pengembangan multimedia yang digunakan pada game edukasi Aksara Sunda Cacarakan ini menggunakan metode pengembang Game Development Life Cycle (2013). Pada pengembangan multimedia versi Game Development Life Cycle memiliki 6 tahapan. (Widyani, 2013).

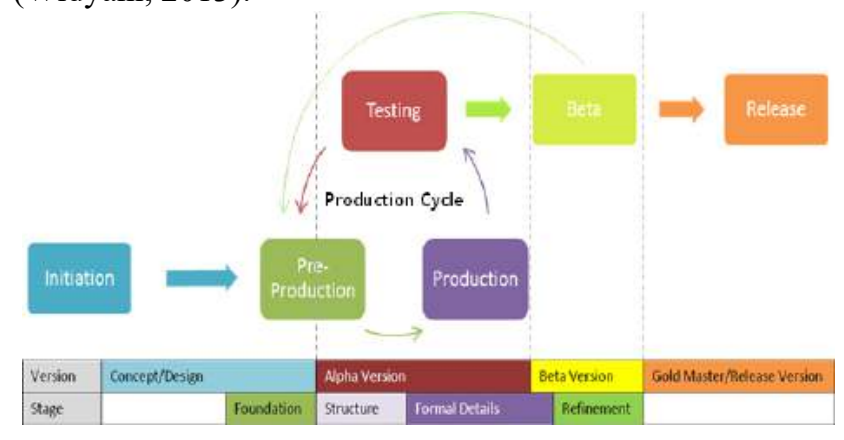

Gambar 2. Tahapan Metode GDLC

1. Initiation (inisiasi)

Tabel II Deskripsi Konsep

\begin{tabular}{ll}
\hline Judul & Penerapan Algoritma Fisher-Yates \\
& Pada Game (Sunda Cacarakan) \\
& Berbasis Android Sebagai Media \\
& Pembelajaran Untuk Anak Usia Dini \\
\hline Tujuan & Sebagai sarana media edukasi dan \\
& memberikan sebuah pengetahuan \\
& umum mengenai pengenalan \\
& dasarAksara Sunda Cacarakan. \\
\hline Pengguna & Dari 6 tahun keatas. \\
Game & \multicolumn{2}{c}{} \\
\hline Interaktivitas & Interaktivitas dalam game ini adalah \\
& penerapan Algoritma Fisher Yates \\
& shuffle, pada pengacakan soal Quis \\
\hline Durasi & Durasi game ini tidak terbatas, \\
& tergantung lamanya pengguna \\
& memainkan game tersebut. \\
\hline Konten & Didalam game ini terdiri dari 2 konten \\
& utama yaitu konten game dan konten \\
& informasi pembelajaran bahasa Sunda \\
& Cacarakan \\
\hline
\end{tabular}

Tahap inisiasi adalah tahap untuk menentukan judul yang pantas untuk permainan tersebut, lalu tujuan dan 
kepada siapa sasaran dari permainan yang akan dibangun. Pada tabel II adalah hasil dari permainan yang telah di inisiasi.

\section{Pre Production}

Pada tahap pre-production dilakukan pembuatan flowchart, storyboard dan struktur navigasi. Berikut adalah rancangan dari flowchart, storyboard dan struktur navigasi untuk membangun sebuah game :

a. Flowchart

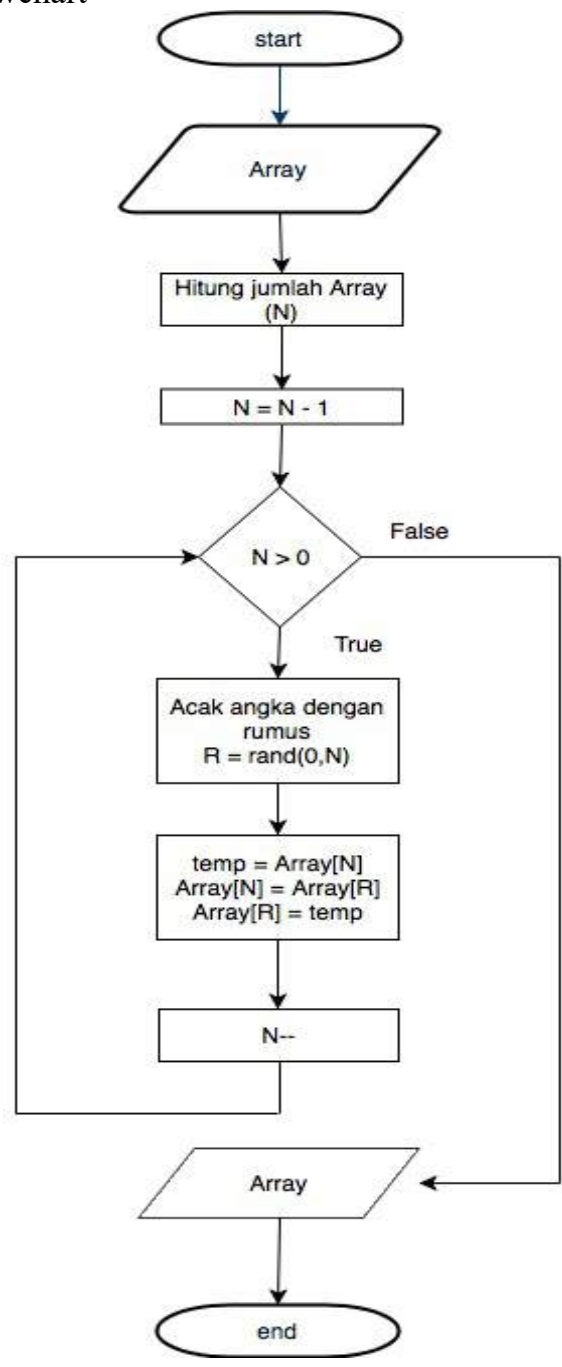

Gambar 3 Flowchart Game Edukasi Aksara Sunda Cacarakan

b. Storyboard

Tabel III Storyboard Game Cacarakan

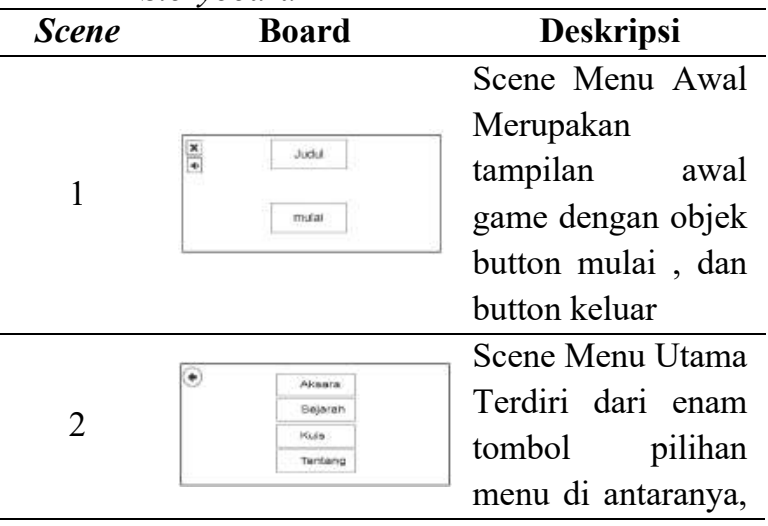

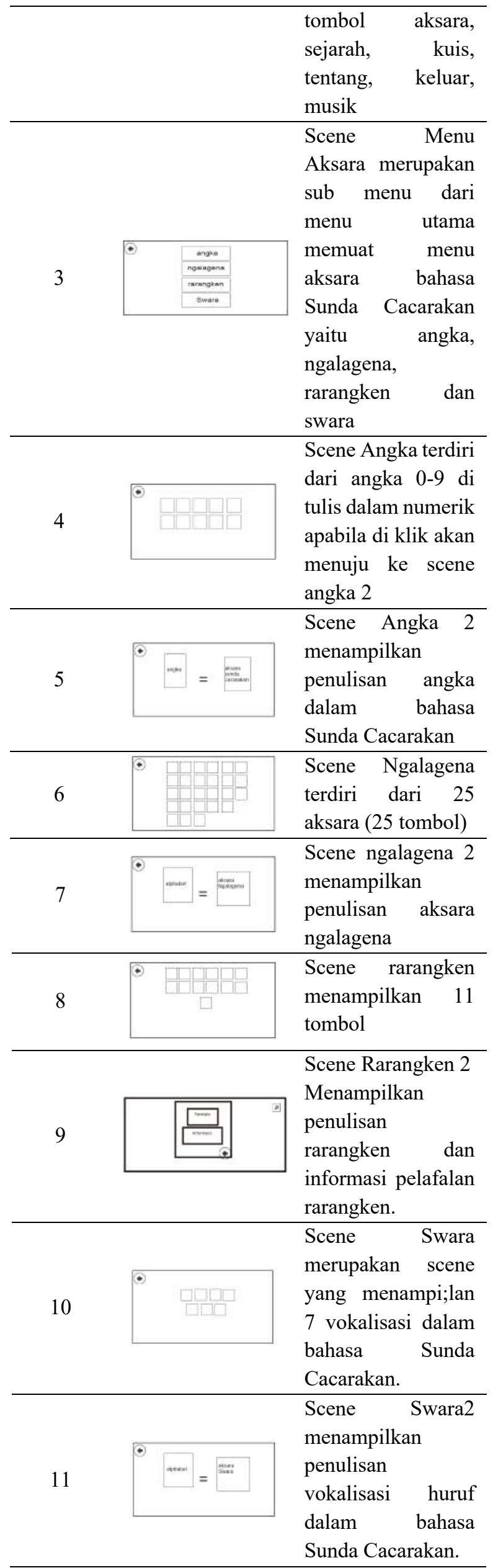




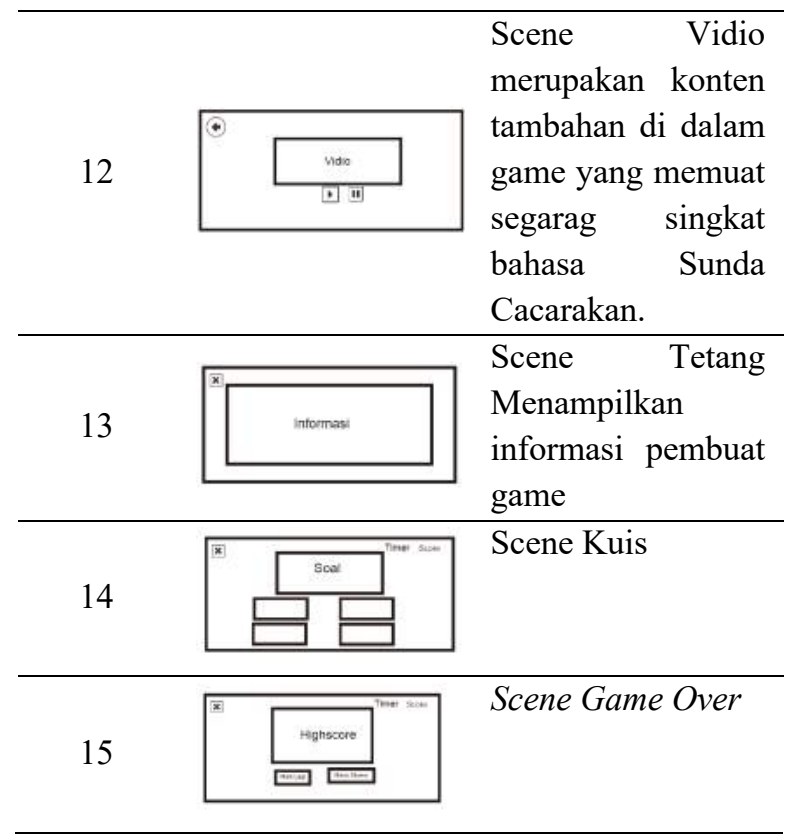

c. Struktur Navigasi

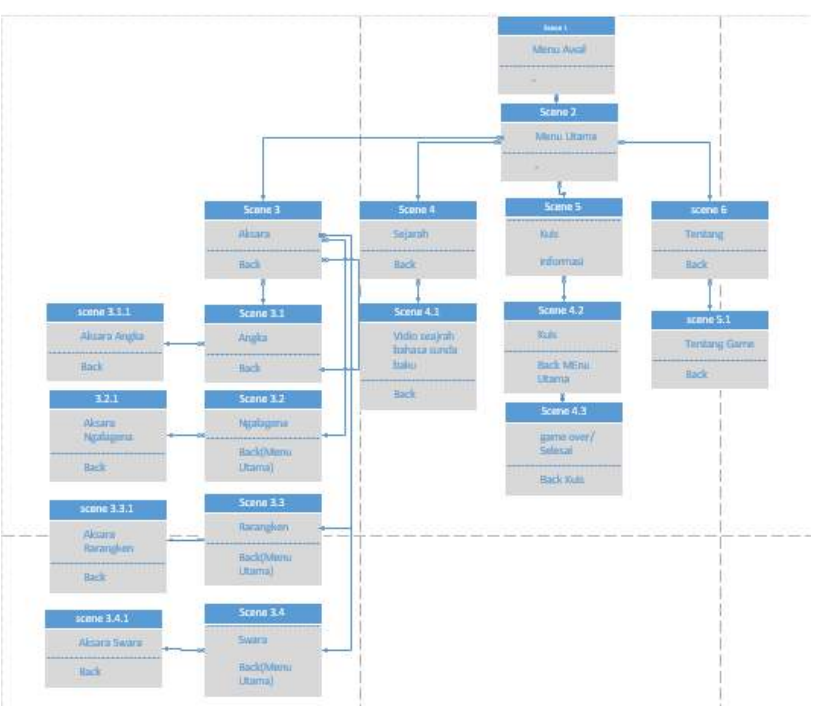

Gambar 4. Struktur Navigasi Aksara Sunda Cacarakan

\section{Production}

a. Aset creation

Tabel IV Asset creation game edukasi Aksara Sunda Cacarakan

\begin{tabular}{|c|c|}
\hline Elemen & Keterangan \\
\hline $\begin{array}{l}\text { Text } \\
\text { (Tulisan) }\end{array}$ & $\begin{array}{l}\text { Element text yang di buat sepenuhnya di } \\
\text { buat menggunakan software Give Your } \\
\text { Fonts Mono v3.1 }\end{array}$ \\
\hline $\begin{array}{l}\text { Image } \\
\text { (Gamba }\end{array}$ & $\begin{array}{l}\text { Elemen Image yang terdapat pada game } \\
\text { sebagian di dapat dari OpenGameArt.com } \\
\text { sebagai acuan acuan untuk contoh } \\
\text { background dan tilemap, dan keseluruhan } \\
\text { desain gambar dibuat dengan menggunakan } \\
\text { software } \\
\text { CorelDraw } x 7 \text { dan Construct } 2 \text {. }\end{array}$ \\
\hline
\end{tabular}

\begin{tabular}{ll}
\hline $\begin{array}{l}\text { Audio } \\
\text { (Suara) }\end{array}$ & $\begin{array}{l}\text { Elemen audio (suara) yang terdapat dalam } \\
\text { game didapat dari website } \\
\text { http://Opengameart.com/ tags-sad.html, }\end{array}$ \\
& $\begin{array}{l}\text { http://soundcloud.com dan dan di } \\
\text { konversikan menggunakan }\end{array}$ \\
& $\begin{array}{l}\text { Situs web } \text { https://audio.online- } \\
\text { convert.com/convert-to- } \text { ogg. Karena }\end{array}$ \\
& $\begin{array}{l}\text { format audio yang di butuhkan } \\
\text { adalah format audio .ogg. }\end{array}$ \\
\hline Animation & $\begin{array}{l}\text { Elemen animasi yang terdapat pada game di } \\
\text { (Animasi }\end{array}$ \\
& buat dengan software Construct 2 dimana \\
file mentah dari gambar yang telah di buat \\
& $\begin{array}{l}\text { (sprite) dengan format .png digabungkan } \\
\text { menjadi sebuah animasi. }\end{array}$ \\
\hline
\end{tabular}

b. Concep art

Tabel V Concept art game edukasi Aksara Sunda Cacarakan

\begin{tabular}{clc}
\hline Objek & Animasi & Polygon Objek \\
Angka & Sprite Objek & \\
\hline $\begin{array}{c}\text { Angka Sunda } \\
\text { Cacarakan }\end{array}$ & Sprite Objek & \\
\hline $\begin{array}{c}\text { Alphabet } \\
\text { Ngalagena }\end{array}$ & $\begin{array}{l}\text { Sprite } \\
\text { Objek }\end{array}$ \\
\hline $\begin{array}{c}\text { Aksara } \\
\text { Ngalagena }\end{array}$ & Sprite Objek & \\
\hline Aksara & Sprite & \\
Rarangken & Objek & \\
\hline
\end{tabular}

$\begin{array}{ccc}\text { Aksara } & \text { Sprite } \\ \text { Objek } & \end{array}$

Aksara Swara Sprite Objek

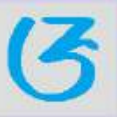

Tombol Back Sprite Objek 


\section{c. Programing}

Pada tahapan ini proses pemberian programing dilakukan menggunakan logic di setiap eventsheet untuk setiap layout yang terdapat pada game menggunakan aplikasi Construct 2.

\section{HASIL DAN PEMBAHASAN}

\subsection{Implementasi Antar Muka}

Penelitian dengan judul Aksara Sunda Cacarakan sudah melewati proses pembuatan dan telah selesai dibuat. Berikut adalah Spesifikasinya:

Persyaratan Sistem minimal :

- OS : Android 4.1 Jelly Bean atau lebih tinggi

- RAM : 512 MB atau lebih tinggi

- Resolusi Layar :1920 x 1080 pixels

1. Halaman Loading

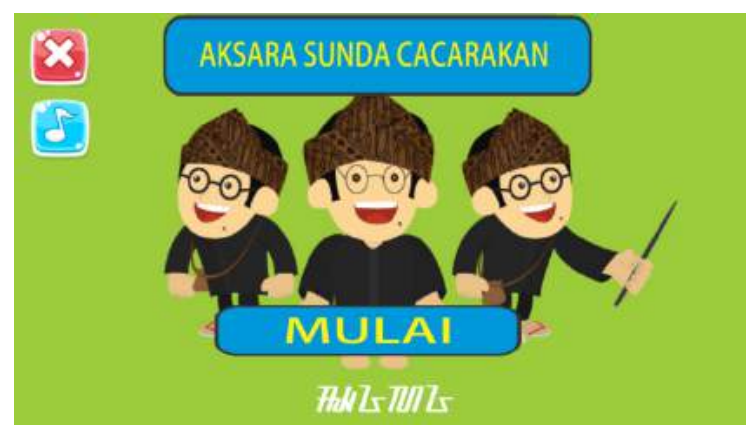

Gambar 5. Halaman Loading

Pada Gambar 5 Menjelaskan halaman awal terdapat dua tombol yaitu tombol keluar dan mulai.

2. Tampilan Menu Utama

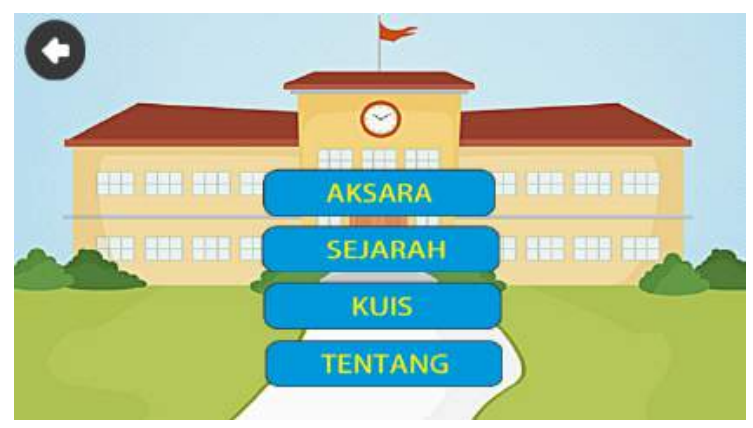

Gambar 6. Tampilan Menu Utama

Pada gambar 6 Menjelaskan halaman menu utama terdapat menu aksara, sejarah, kuis, tentang dan dua tombol keluar dan musik.

\section{Tampilan Aksara}

Pada gambar 7 Menjelaskan halaman aksara terdapat 4 sub menu angka, ngalagena, rarangken, dan swara, terdapat dua tombol keluar dan musik.

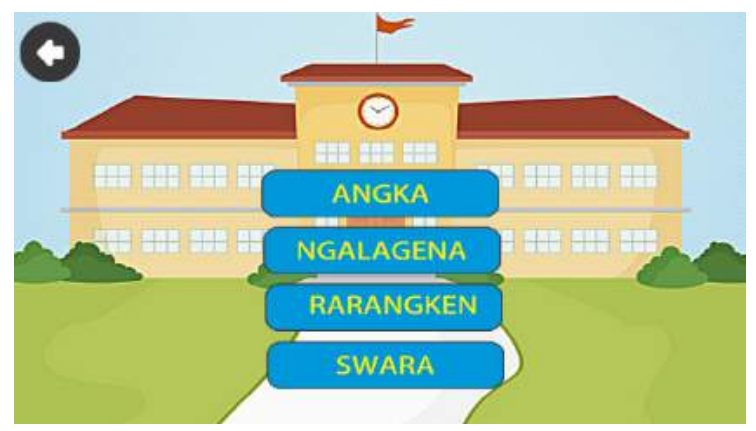

Gambar 7. Tampilan Aksara

4. Tampilan Swara

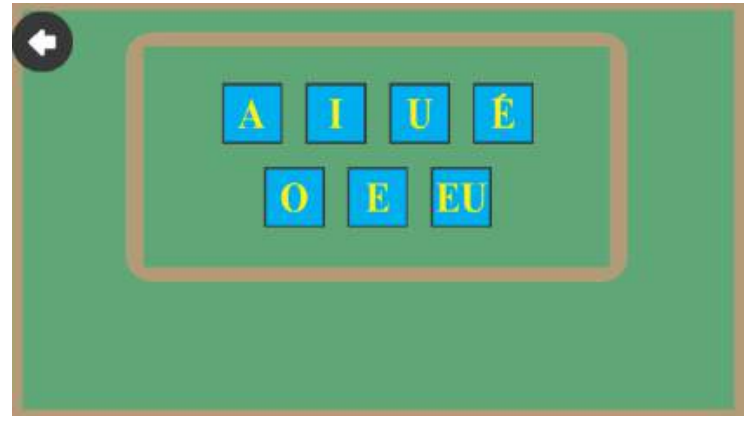

Gambar 8. Tampilan Swara

Pada halaman swara terdapat tujuh tombol swara, tombol back ke halaman menu dan tombol sound

5. Tampilan Halaman Angka

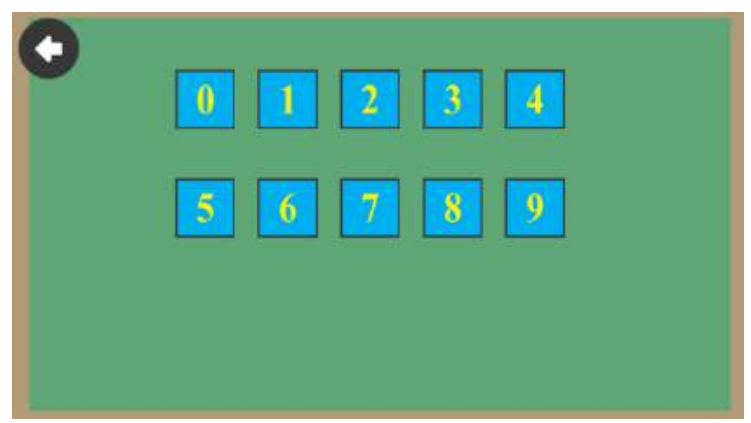

Gambar 9. Tampilan Halaman Angka

Pada halaman angka terdapat sepuluh tombol angka, tombol back ke halaman menu dan tombol sound.

6. Tampilan Rarangken

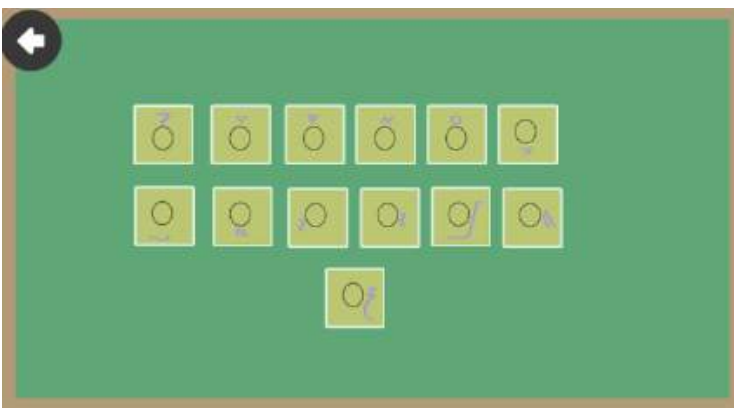

Gambar 10.Tampilan Halaman Rarangken 
Pada halaman rarangken terdapat tiga belas tombol rararangken, tombol back ke halaman menu dan tombol sound

7. Tampilan Halaman Ngalagena

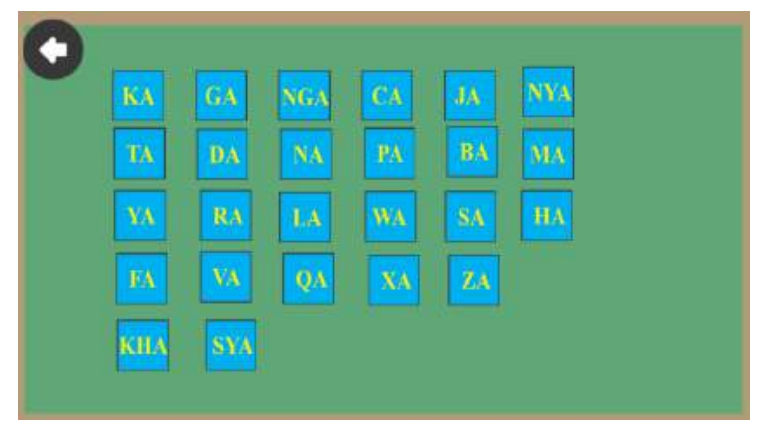

Gambar 11. Tampilan Halaman Ngalagena

Pada gambar 11 Menjelaskan halaman ngalagena terdapat dua puluh lima tombol ngalagena, tombol back ke halaman menu dan tombol sound.

\section{Halaman Quis}

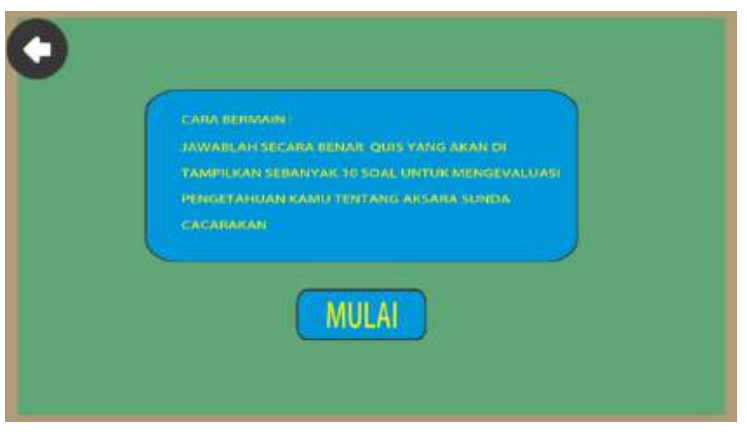

Gambar 12. Halaman Quis

Pada Gambar 12 Menjelaskan halaman quis terdapat keterangan cara bermain, tombol mulai untuk melanjutkan ke halaman pertanyaan, tombol back ke halaman utama dan tombol musik.

\section{Halaman Sejarah}

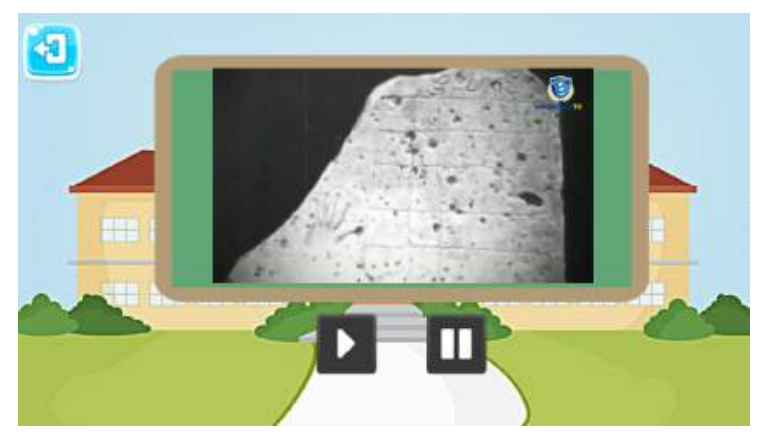

Gambar 13. Halaman Sejarah

Pada Gambar 13 Menjelaskan halaman sejarah terdapat konten video sejarah aksara Sunda Cacarakan, tombol pause dan play dan tombol back ke halaman menu utama.
10. Tampilan informasi layout pembuat game

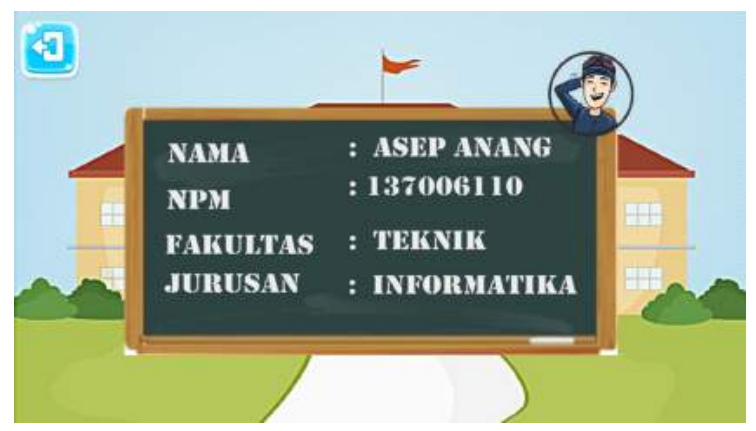

Gambar 14. Halaman Tentang

Pada gambar 14 Menjelaskan Halaman tentang menampilkan informasi pembuat dan tombol back kembali ke halaman utama.

11. Halaman Pertanyaan

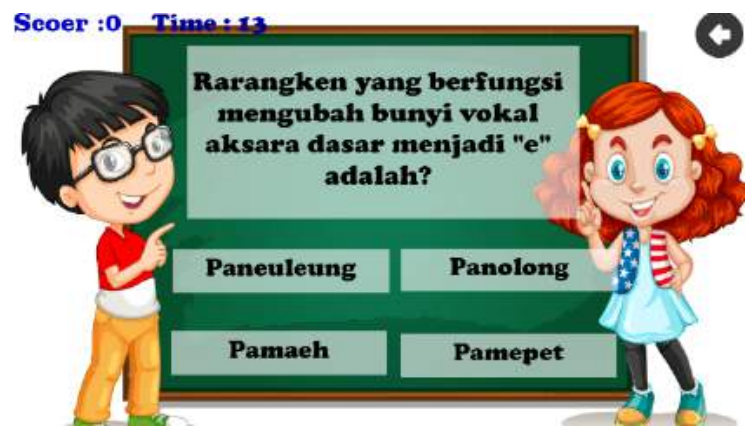

Gambar 15. Halaman Pertanyaan

Pada Gambar 15 Menjelaskan halaman pertanyaan di tampilkan pertanyaan score, timer dan tombol bvack ke halaman utama.

12. Halaman Game Over

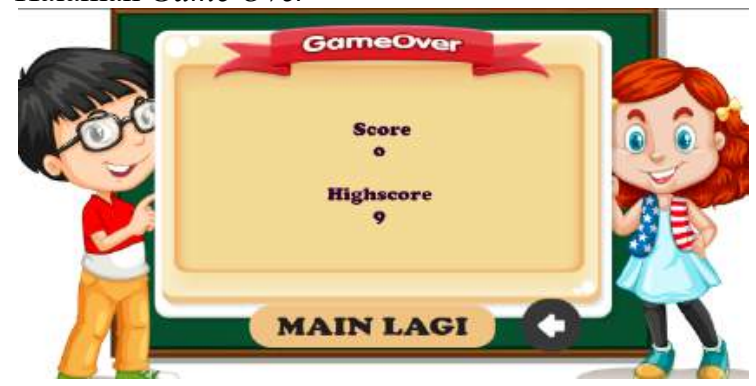

Gambar 16. Tampilan Menu Game Over

Pada Gambar 16 Menjelaskan halaman game over menampilkan score yang di raih dan high score, terdapat tombol main lagi dan tombol back ke halaman menu utama.

\subsection{Testing}

Untuk Mengetahui apakah sistemsudah sesuai dengan keinginan atau ada kesalahan, guna meminimalisir kesalahan pada game yang dibut. Dalam tahapan testing menggunakan Alpha (Alpha testing) dan Beta (Beta Testing). 
Tabel VI Alpha Testing

\begin{tabular}{|c|c|c|c|}
\hline Layout & $\begin{array}{c}\text { Detail } \\
\text { Pengujian }\end{array}$ & $\begin{array}{c}\text { Hasil Yang } \\
\text { Diharapkan }\end{array}$ & $\begin{array}{c}\text { Hasil } \\
\text { Pengujian }\end{array}$ \\
\hline $\begin{array}{l}\text { Halaman } \\
\text { Awal }\end{array}$ & $\begin{array}{l}\text { Menekan } \\
\text { tombol } \\
\text { mulai }\end{array}$ & $\begin{array}{l}\text { Scene halaman awal } \\
\text { akan berganti ke } \\
\text { scene halaman menu }\end{array}$ & $\begin{array}{l}{[\sqrt{ }] \text { diterima }} \\
{[\text { ] ditolak }}\end{array}$ \\
\hline \multirow[t]{7}{*}{$\begin{array}{l}\text { Menu } \\
\text { utama }\end{array}$} & $\begin{array}{l}\text { Memilih } \\
\text { tombol } \\
\text { Aksara } \\
\end{array}$ & $\begin{array}{l}\text { Menampilkan menu } \\
\text { pilih level }\end{array}$ & $\begin{array}{l}{[\sqrt{ }] \text { diterima }} \\
{[\mathrm{]}] \text { ditolak }}\end{array}$ \\
\hline & $\begin{array}{l}\text { Memilih } \\
\text { tombol } \\
\text { Sejarah }\end{array}$ & $\begin{array}{l}\text { Menampilkan scene } \\
\text { sejarah }\end{array}$ & $\begin{array}{l}{[\sqrt{ }] \text { diterima }} \\
{[\mathrm{]} \text { ditolak }}\end{array}$ \\
\hline & $\begin{array}{l}\text { Memilih } \\
\text { tombol } \\
\text { kuis } \\
\end{array}$ & $\begin{array}{l}\text { Menampilkan menu } \\
\text { kuis }\end{array}$ & $\begin{array}{l}{[\sqrt{ }] \text { diterima }} \\
{[\mathrm{]}] \text { ditolak }}\end{array}$ \\
\hline & $\begin{array}{l}\text { Memilih } \\
\text { tombol } \\
\text { tentang }\end{array}$ & $\begin{array}{l}\text { Menampilkan } \\
\text { informasi tentang } \\
\text { pembuat }\end{array}$ & $\begin{array}{l}{[\sqrt{ }] \text { diterima }} \\
{[\mathrm{]}] \text { ditolak }} \\
\end{array}$ \\
\hline & $\begin{array}{l}\text { Memilih } \\
\text { tombol } \\
\text { musik }\end{array}$ & $\begin{array}{l}\text { Menghentikan dan } \\
\text { memulai musik } \\
\text { kembali apabila di } \\
\text { touch kembali }\end{array}$ & $\begin{array}{l}{[\sqrt{ }] \text { diterima }} \\
{[\text { ] ditolak }}\end{array}$ \\
\hline & $\begin{array}{l}\text { Memilih } \\
\text { tombol } s f x\end{array}$ & $\begin{array}{l}\text { Menghentikan dan } \\
\text { memulai efek suara } \\
\text { kembali apabila di } \\
\text { touch kembali }\end{array}$ & $\begin{array}{l}{[\sqrt{ }] \text { diterima }} \\
{[\mathrm{]}] \text { ditolak }}\end{array}$ \\
\hline & $\begin{array}{l}\text { Memilih } \\
\text { tombol } \\
\text { keluar } \\
\end{array}$ & Keluar dari game & $\begin{array}{l}\sqrt{ }] \text { diterima } \\
{[\mathrm{]} \text { ditolak }}\end{array}$ \\
\hline \multirow[t]{2}{*}{ Kuis } & $\begin{array}{l}\text { Memilih } \\
\text { jawaban } \\
\text { yang benar }\end{array}$ & $\begin{array}{l}\text { Menambahkan point } \\
\text { ker highscore } \\
\text { sementara }\end{array}$ & $\begin{array}{l}{[\sqrt{ }] \text { diterima }} \\
{[\mathrm{]} \text { ditolak }}\end{array}$ \\
\hline & $\begin{array}{l}\text { Memilih } \\
\text { jawaban } \\
\text { yang salah }\end{array}$ & $\begin{array}{l}\text { Mengakhiri scene } \\
\text { kuis dan berpindah } \\
\text { ke scene game over }\end{array}$ & $\begin{array}{l}{[\sqrt{ }] \text { diterima }} \\
{[\mathrm{]} \text { ditolak }} \\
\end{array}$ \\
\hline \multirow[t]{4}{*}{$\begin{array}{c}\text { Aksara } \\
\text { Sunda } \\
\text { Cacarakan }\end{array}$} & $\begin{array}{l}\text { Menekan } \\
\text { tombol } \\
\text { Abjad } \\
\text { alphabet } \\
\text { rarangken }\end{array}$ & $\begin{array}{l}\text { Menampilkan bentuk } \\
\text { huruf aksara Sunda } \\
\text { Cacarakan rarangken }\end{array}$ & $\begin{array}{l}{[\sqrt{ }] \text { diterima }} \\
{[\text { ] ditolak }}\end{array}$ \\
\hline & $\begin{array}{l}\text { Menekan } \\
\text { tombol } \\
\text { Angka }\end{array}$ & \begin{tabular}{lr}
\multicolumn{2}{l}{ Menampilkan bentuk } \\
angka & Sunda \\
Cacarakan & \\
\end{tabular} & $\begin{array}{l}{[\sqrt{ }] \text { diterima }} \\
{[\text { ] ditolak }} \\
\end{array}$ \\
\hline & $\begin{array}{l}\text { Menekan } \\
\text { tombol } \\
\text { Abjad } \\
\text { alphabet } \\
\text { swara }\end{array}$ & $\begin{array}{l}\text { Menampilkan bentuk } \\
\text { huruf aksara Sunda } \\
\text { Cacarakan swara }\end{array}$ & $\begin{array}{l}{[\sqrt{ }] \text { diterima }} \\
{[\mathrm{]}] \text { ditolak }}\end{array}$ \\
\hline & $\begin{array}{l}\text { Menekan } \\
\text { tombol } \\
\text { Abjad } \\
\text { alphabet } \\
\text { ngalagena }\end{array}$ & $\begin{array}{l}\text { Menampilkan bentuk } \\
\text { huruf aksara Sunda } \\
\text { Cacarakan ngalagena }\end{array}$ & $\begin{array}{l}{[\sqrt{ }] \text { diterima }} \\
{[\mathrm{]} \text { ditolak }}\end{array}$ \\
\hline \multirow[t]{2}{*}{ Tentang } & $\begin{array}{l}\text { Menekan } \\
\text { tombol } \\
\text { kembali }\end{array}$ & $\begin{array}{l}\text { Menampilkan menu } \\
\text { utama }\end{array}$ & $\begin{array}{l}{[\sqrt{ }] \text { diterima }} \\
{[] \text { ditolak }}\end{array}$ \\
\hline & $\begin{array}{l}\text { Menekan } \\
\text { tombol } \\
\text { tentang } \\
\end{array}$ & $\begin{array}{l}\text { Menampilkan } \\
\text { informasi tentang } \\
\text { game }\end{array}$ & $\begin{array}{l}{[\sqrt{ }] \text { diterima }} \\
{[\mathrm{]} \text { ditolak }}\end{array}$ \\
\hline Sejarah & $\begin{array}{l}\text { Menekan } \\
\text { tombol } \\
\text { play }\end{array}$ & $\begin{array}{l}\text { Menampilkan video } \\
\text { sejarah aksara Sunda } \\
\text { Cacarakan }\end{array}$ & $\begin{array}{l}{[\sqrt{ }] \text { diterima }} \\
{[\mathrm{]}] \text { ditolak }}\end{array}$ \\
\hline
\end{tabular}

Berdasarkan hasil pengujian alpha (fungsional) dengan kasus uji diatas dapat ditarik kesimpulan bahwa dalam pembangungn game edukasi Aksara Sunda Cacarakan tidak terdapat kesalahan proses dan secara fungsional mengeluarkan hasil yang sesuai dengan yangdiharapkan.
Tabel VII Jumlah Responden

\begin{tabular}{ccccccc}
\hline \multirow{2}{*}{$\begin{array}{c}\text { Aspek } \\
\text { Ke }\end{array}$} & \multicolumn{5}{c}{ Jumlah Penelitian } & Jumlah \\
\cline { 2 - 5 } & SS & S & KS & TS & STS & Responden \\
\hline 1 & 5 & 11 & 4 & 0 & 0 & 20 \\
\hline 2 & 7 & 9 & 4 & 0 & 0 & 20 \\
\hline 3 & 12 & 4 & 4 & 0 & 0 & 20 \\
\hline 4 & 8 & 11 & 1 & 0 & 0 & 20 \\
\hline 5 & 4 & 14 & 2 & 0 & 0 & 20 \\
\hline
\end{tabular}

\subsection{Evaluasi Pengguna}

Evaluasi pengguna game, dilakukan kepada 20 responden. Berisikan 5 pertanyaan kepada 20 respoden yang telah memainkan. Penilaian tanggapan dari responden ini menggunakan skala likert. Skala likert memiliki 5 respon dan memiliki nilai tersendiri. Titik respon skala likert dan bobot nilainya antara lain sebagai berikut:

Sangat Setuju (SS) $\quad: 5$

Setuju (S) : 4

Kurang Setuju (KS) : 3

Tidak Setuju (TS) : 2

Sangat Tidak Setuju (STS) $\quad: 1$

Tabel VIII Hasil Akhir

\begin{tabular}{lll}
\hline \multicolumn{1}{c}{ Aspek } & \multicolumn{1}{c}{$\begin{array}{c}\text { Pertanyaan } \\
\text { Ke }\end{array}$} & Index \\
\hline \multirow{2}{*}{ Kegunaan } & 1 & $78 \%$ \\
\cline { 2 - 3 } & 2 & $83 \%$ \\
\hline \multirow{2}{*}{ Kualitas Interaksi } & 3 & $88 \%$ \\
\hline Kualitas Informasi & 4 & $87 \%$ \\
\hline
\end{tabular}

Dari tabel VIII menunjukan hasil akhir pengujian Game Edukasi Aksara Sunda Cacarakan Berbasis Android dapat di ambil rata-rata rumus index sebagai berikut :

a) Aspek kegunaan kegunaan (Pertanyaan ke-1 dan 2) :

Pertanyaan pertama $=78 \%$

Pertanyaan kedua $=83 \%$

Sehingga diperoleh index rata-rata $=80,5 \%$

b) Aspek Kualitas Interaksi (Pertanyaan ke-3 dan 4) :

Pertanyaan ketiga $=88 \%$

Pertanyaan keempat $=87 \%$

Sehingga diperoleh indeh rata-rata $=87,5 \%$

c) Kualitas Informasi (Pertanyaan ke-5) :

Pertanyaan kelima $=82 \%$

Sehingga diperoleh index rata-rata $=82 \%$

Berdasarkan rata-rata rumus index yang diperoleh dari responden, aspek kegunaan sebesar 80,5\%, aspek kualitas interaksi sebesar $87,5 \%$ dan aspek kualitas informasi sebesar $82 \%$, termasuk dalam kategori sangat setuju, sehingga game dinyatakan layak untuk digunakan dan dipublikasikan. 


\section{KESIMPULAN}

Dari hasil pembahasan yang telah diuraikan, maka telah di hasilkan sebuah Game edukasi Aksara Sunda Cacarakan berbasis Android untuk memberikan latihan dan pemahaman kepada pengguna (anak usia dini) sehingga dapat memahami Aksara Sunda Cacarakan.

Adapun beberapa saran untuk pengembangan selanjutnya dilihat dari kekurangan perlu ditambahkan lagi jumlah pertanyaan, pengujian dengan menggunakan algoritma pengacakan soal yang lain.

\section{DAFTAR PUSTAKA}

[1] Mhd Arief Hasan, Supriadi,Zamzami.2017. Implementasi Algoritma Fisher-Yates Untuk Mengacak Soal Ujian Online Penerimaan Mahasiswa Baru (Studi Kasus : Universitas Lancang Kuning Riau) .UNLAK.

[2] Anggraini,Fitri,Arifiati.2016.Aplikasi Game Edukasi Petualangan Nusantara.Semarang.

[3] Rizky,Muhammad.2016.Perancangan Game Math Adventure Sebagai Media Pembelajaran Matematika Berbasis Android.Semarang.

[4] Dyah Ayu Irawati. (2017). PENERAPAN ALGORITMA FISHER-YATES PADA PENGACAKAN SOAL GAME ARITMATIKA.

[5] Bobby, Prasetyo.2015. PERANCANGAN MEDIA PEMBELAJARAN BERHITUNG BERBASIS MULTIMEDIA FLASH. Yogyakarta.

[6] Permana, B., Hidayat, E. W., \& Rahmatulloh, A. (2018). Aplikasi Ensiklopedia Pakaian Adat Dunia Berbasis Android. Jurnal Informatika: Jurnal Pengembangan IT, 3(2), 151-156.

[7] Aksara, P. P. (1999). Sunda Kuno Melalui Naskah Bima Swarga 623. 2(1), 1-15.

[8] Ernawati, R. S., Hidayat, E. W., \& Rahmatulloh, A. (2017). Implementasi Teknologi Augmented Reality Sebagai Media Pengenalan Aksara Sunda Berbasis Android. Jurnal Teknik Informatika Dan Sistem Informasi, 3(3).

[9] Bagus, I., Adi, K., Buana, P. W., \& W, A. A. K. A. C. (2015). Game Edukasi Rambu Lalu Lintas Berbasis Android. Merpati, 3(3), 190-201.

[10] Vega, A. (2016). Game edukasi sebagai media pembelajaran pendidikan anak usia dini. Inform, I(1), 1-8.

[11] Widyani, R. R. and Y. (2013). Game development life cycle guidelines," 2013 International Conference on Advanced Computer Science and Information Systems (ICACSIS). Pp. 95-100.

\section{BIODATA PENULIS}

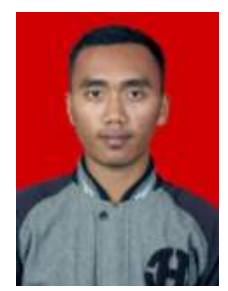

Asep Anang

Merupakan mahasiswa jurusan

informatika Universitas Siliwangi.

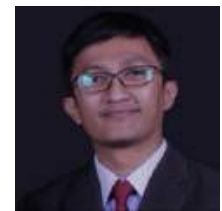

Acep Irham G

Merupakan dosen Jurusan Informatika

Universitas Siliwangi. 